\title{
LAND ADMINISTRATION SUPPORT FOR POST-DISASTER MANAGEMENT
}

\author{
N. Vučić ${ }^{*}$, M. Mađer ${ }^{1}$, D. Pivac $^{2}$ *, M. Roić ${ }^{2}$ \\ ${ }^{1}$ DEMLAS project - Faculty of Geodesy, University of Zagreb, Kačićeva 26, 10000 Zagreb, Croatia - (nikola.vucic, \\ mmadjer)@gmail.com \\ ${ }^{2}$ Faculty of Geodesy, University of Zagreb, Kačićeva 26, 10000 Zagreb, Croatia - (dopivac, mroic)@ geof.hr
}

KEY WORDS fire hazard, land administration, monitoring, fire management system, compensations

\begin{abstract}
:
In the Republic of Croatia, especially during the summer times, fire hazards represent a real threat for vegetation and animals but also for material goods and human lives. The most affected areas are those in the coastal region which is characterized by very dry environment and strong winds which is suitable for rapid spread of fire. Even though the prevention of fire is an utmost imperative, Republic of Croatia is still missing a good and reliable fire management system for fire monitoring but also for post-disaster management. The results of currently ongoing scientific project "Development of Multipurpose Land Administration System DEMLAS" could be of an assistance. The aim of the DEMLAS project is to create a prototype of a modern multipurpose land administration system that supports all land governance activities. It could be used for identifying dangerous locations where fires repeatedly occur and together with other relevant data provide a solution for better monitoring and prediction of the fires. It could also be used for identifying the land parcels for compensations for damages and losses after the fire devastations. The Island of Hvar which is also affected by this problem will serve as a test case for quick and relevant calculation of compensations based on official registered data.
\end{abstract}

\section{INTRODUCTION}

The concept of disaster management represents a special area management. It is an integral part of the functioning of civil institutions as the risk and crisis (real or perceived) are an integral part of human daily life. Moreover, the importance of the institute of crisis management can be seen in the fact that many countries around the world have established a special government agencies (for example, the US federal agency for crisis management / Federal Emergency Management Agency), and some of them even ministries (Russian Federation), with the aim of developing and integration of national capacity for effective crisis management.

A disaster can be defined in various ways. However, all of them are related to natural and human caused events that result in loss of life, injury or other health impacts, property damage, loss of livelihoods and services, social and economic disruption, or environmental damage.

The United Nations for Disaster Risk Reduction (UNISDR) defines disaster as a serious disruption of the functioning of a community or a society involving widespread human, material, economic or environmental losses and impacts, which exceeds the ability of the affected community or society to cope using its own resources (URL 1). According to International Federation of Red Cross and Red Crescent Societies, a disaster is combination of hazard, vulnerability and capacity of society to cope with negative consequences of hazard events. It can be described by the following expression:

$$
\text { DISASTER }=\frac{\text { HAZARD }+ \text { VULNERABILITY }}{\text { CAPACITY }}
$$

Hazard refers to every phenomenon, substance, human activity or condition that may have negative consequences on people, property, environment, economy and society, loss of flora and fauna. It can arise from a variety of geological, meteorological, hydrological, oceanic, biological, and technological sources, sometimes acting in combination.

Vulnerability describes the susceptibility of community to disaster arising from different physical, social, economic, and environmental factors like insufficient level of information and awareness of people, poor construction of buildings, inadequate protection of assets etc. Vulnerability varies significantly within community and over time.

Coping capacity is ability to deal with emergency situations and react when disaster happens. Coping capacities contribute to the reduction of disaster risks.

Disasters can be classified in several ways. They can be classified based on their origin, territorial coverage, way of appearance and duration. However, most common classification is based on origin, which is natural or anthropogenic, i.e. human caused.

Natural disasters are result of natural hazards whose consequences have an impact on humanity, property and the environment. During the past, the number of natural disasters has increased which can be attributed to climate change, people growth and economic development. The most frequent natural hazards are earthquakes, floods, landslides, storms, tsunamis, avalanches and wildfires. Human caused disasters are a result of human intent, negligence or error or can be a consequence of failure of human - made systems. Although they are less destructive than natural disasters they can also cause losses of life, huge material damage on property and infrastructure. Human caused disasters can be classified in sociological and technological hazards.

* Corresponding author 
The development of modern global geodetic surveying methods, including the remote sensing and satellite measurements such as satellite gravimetry and altimetry, along with the development of information technologies and data distribution capabilities, allows for the improvement of spatial data registers. These include utilizing the existing registers and building up the new ones in order to enable crisis situations risk management, i.e. managing the risk from natural disasters such as earthquakes, fires, floods, droughts, and landslides (Jukić et al. 2017).

For example, the preparation phase of disaster management has been approached with a GIS (Geographic Information System) based MCDA (Multi-Criteria Decision Analysis) (G-MCDA) vision and an example of determination of the susceptibility of the flood and overflow (Yalcin et al. 2012).

Geospatial Consortium, Infrastructure for Spatial Information in the European Community (INSPIRE) or the Global Monitoring for Environment and Security (GMES), for example, increasingly facilitates the exchange of geographic information and services. Nevertheless, the emergency response sectors and/or other local organizations often maintain much of the information. Sometimes, it is unclear whether two emergency sectors possess the same information; maps and plans maintained by the police brigade might be not available for ambulances or fire department. This tendency is very strong in the case of spatial information. The different sectors used to have individual information systems for management of information, which could not communicate with each other and therefore were unable to share information (Zlatanova et al. 2012).

Post-fire environmental footprint is expected at varying scales in space and in time and demands development of multi-scale monitoring approaches. Integration of the multi-resources information with a multi-scale model, characterized by scalespecific assessment tools and methods, proves successful to identify micro-topographical processes affecting the post-fire area at various scale in space and in time (Brook et al. 2017).

Statistics prove that the number of disasters, especially weatherrelated, increased during the last decades. This leads to high demands on participants in disaster management processes. To meet these requirements the provision of geodata, as a part of the information base, plays a key role (Fleischhauer et al. 2017).

Wildfires in the Republic of Croatia in 2017 caused numerous devastations both on forest and agricultural land. Mostly they occurred in the area of Dalmatia, including the island of Hvar. Hvar is especially significant for this paper as it is also a test field for ongoing scientific project DEMLAS (Development of Multipurpose Land Administration System). A fire that broke out on August $21^{\text {st }} 2017$ on island Hvar reached Cape Kabal where torched mostly agricultural land, including olive groves, vineyards and orchards. Although affected area and the resulting damages were not extremely large, the mentioned location - according to abovementioned reason - has been selected as the test field for proofing the concept.

The aim of the paper is to show the utilization of modern technologies in the case of natural disasters for the purpose of identification of affected cadastral parcels and calculation of compensations for land owners. It was achieved by using the established DEMLAS platform, Sentinel-2 satellite images and official cadastral data.
The paper is organized as follows. The first section of the paper is introduction. The second deals with system of compensations in Republic of Croatia. Third section gives an overview of some geolocation indicators of selected test area. The fourth section describes the methodology applied in this subject. Fifth section represents the results of data analysis and the final section is conclusion.

\section{SYSTEM OF COMPENSATIONS IN REPUBLIC OF CROATIA}

In the Republic of Croatia there are many types of insurances. The most important classification is:

- $\quad$ life insurance (life insurance, supplementary pension insurance, voluntary pension insurance and other types of life insurances)

non-life insurance (accident insurance, motor vehicle insurance, fire and other risks insurance for real properties, flood risk insurance for real properties, motor vehicle liability insurance, etc.).

The system of real property insurance for various damages is less developed than the system of insurance for motor vehicles (compulsory insurance) and the system of life insurance for natural persons. As far as real properties are concerned, in most cases houses and flats are being insured, but also in some cases farmers also want to insure their crops against potential damage caused by natural disasters by paying agricultural and crop insurance, to be eligible for damage compensations.

In the Republic of Croatia, natural disaster can be classified as earthquake, storm wind, fire, flood, drought, hail, frost, snowdrift, avalanche, ice on watercourse, landslide, epidemic, plant disease, soil pollution, water pollution, air pollution and other disasters.

According to the Methodology for damage assessment in case of natural disasters (Official Gazette 1998), damage can be determined for the following categories: buildings, equipment, land, long-term crops, forests, livestock, working assets and other assets and goods. The damage is expressed as the monetary value necessary to bring the damaged or destroyed property into a state which preceded natural disaster; or as value needed to obtain such goods in quantity and quality which existed prior to the natural disaster. Damage assessment is done for settlements, municipalities, cities, counties or the whole territory of the Republic of Croatia. The smallest assessment unit for natural persons is the household and for non-natural persons the full non-natural person. For buildings, the smallest damage assessment unit is one structural unit (e.g. building) regardless of the number of flats, owners, users and households. Costs related to the damage assessment in case of natural disasters are associated with the territorial unit in which they appeared. Compensation values for devastated land is calculated by determining the damage category and affected area in hectares and multiplying it with the corresponding prices.

The final report on natural disaster (used to obtain compensation) has the following content:

- $\quad$ Type and description of the natural disaster, the names of settlements and cities / municipalities affected by the disaster (basic characteristics of disaster, size of affected area), 
- Data on influence on public life and economy,

- Data on human casualties (died, injured, ill, evacuated),

- $\quad$ Property insurance data (data from insurance companies),

- Costs of eliminating direct consequences of natural disaster,

- $\quad$ Damage assessment due to natural disaster (halt of production, work, disturbances in non-productive activities such as education, health, culture, sport, social welfare),

- Data on received aid from the country and abroad,

Evaluation of self-help in eliminating the consequences,

Organization of mitigation and removal of disaster consequences,

- Data on the productivity of damaged agricultural crops and long-term crops (three-year average of the county per hectare, tree, grape vine),

- $\quad$ The budget of the city / municipality and county in the previous year,

- The decision of the local self-government and government to reduce or exempt from tax payment and the overall financial effect of that decision,

- The overview of prices used in the assessment,

Damage documentation (forms, tables, photo documentation).

In most developing countries, the land administration system is not highly developed and does not reflect the real field situation. It is often the case that only urban areas have up-todate registered data. Most of the fires in the Republic of Croatia are breaking out on forest and agricultural land (Španjol et al. 2013), where property-legal matters are often not clear.

First problem facing the people with properties damaged or destroyed during the wildfires is the untidy ownership documentation, non-registered buildings and non-registered actual land use in official registers. Other problem is the time needed to get compensation after the damage is determined. The reason for this very often lies in local land administration institutions lacking the capacity to promptly process and make decision about compensations. Increasing the capacity of land institutions responsible for damage determination in the highrisk disaster area would bring improvements, but in countries such as Croatia, lack of financial resources often presents obstacle. Visitation of destroyed areas, positioning and measuring, as well as ownership verification is very demanding and time-consuming task. Therefore, the service with satellite system support could significantly accelerate the decisionmaking process for the compensation claims of beneficiaries, by determining the scale of the disaster, recognizing and establishing the rights and calculating the level of compensation.

\section{TEST FIELD AND DATA}

The test field for this research, cape Kabal on the Island of Hvar (Figure 1), is located in the northwestern part of the island with the geographic coordinates: $43^{\circ} 13^{\prime} 00^{\prime \prime} \mathrm{N}, 16^{\circ} 32^{\prime} 00^{\prime \prime} \mathrm{E}$. According to division into cadastral spatial units Kabal belongs to the cadastral municipality Stari Grad. Given its geographic position and its affiliation to the Mediterranean countries, the risk of coastal fires in the Croatian coastal zone and on the islands is emphasized, especially during the summer months which are characterized by extreme meteorological conditions (high temperature and very dry air, strong and specific wind, lightning strikes).

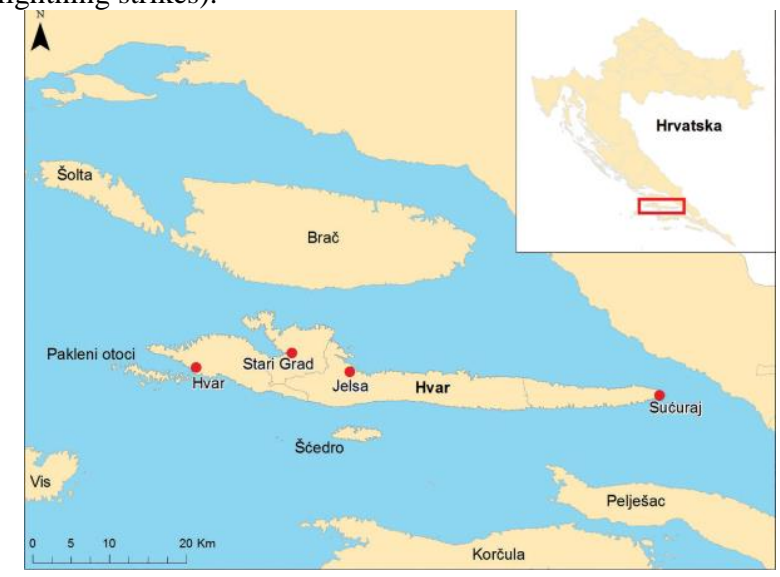

Figure 1. Geographic location of the Island of Hvar (Mamut and Čirjak 2017)

Fires which spread out on agricultural areas for food production result in great economic damages which are very difficult to recover from, high revitalization costs and other indirect and immediate losses. Wildfires on agricultural land are characterized by the following facts (DUZS 2015):

- the vulnerability of agricultural crops (olive groves, vineyards, etc.) is especially emphasized during the dry periods

- $\quad$ direct and indirect material damage, production halts, need for soil recovery

- $\quad$ highly inaccessible terrains for firefighting equipment

once cultivated land, now no longer maintained which enables the environment with plenty of evergreen trees and shrubs which are very suitable for starting the fire

About $75 \%$ of forest fires in the Republic of Croatia occur in Mediterranean forests, in regard to continental forests. About $90 \%$ of total fire devastated areas refers to karstic areas - typical for coastal zone.

For the purpose of this research, Sentinel-2 L1C satellite images and official cadastral data have been collected. Satellite image showing the fire devastated area on August $31^{\text {st }} 2017$ has been located on Sentinel Web site (URL 2). Figure 2 shows the Sentinel images for the cape Kabal before (a) and after the fire (b).

The Sentinel-2 mission is a land monitoring constellation of two satellites (Sentinel-2A and Sentinel-2B) that provide high resolution optical imagery. The mission provides a global coverage of the Earth's land surface every 10 days with one satellite (and 5 days with 2 satellites), making the data of great use in on-going studies. Sentinel-2 delivers high-resolution optical images for land monitoring, emergency response and security services. The satellite carries a multispectral imager with a swath of $290 \mathrm{~km}$ (URL 2).

The Multi Spectral Instrument (MSI) on-board Sentinel-2 can record the information in Vegetation Red-Edge (VRE) spectral domains (Qiu et al. 2017). The imager provides a versatile set 
of 13 spectral bands spanning from the visible and near infrared to the shortwave infrared, featuring four spectral bands (B2, B3, $\mathrm{B} 4$ and B8) at 10m, six bands (B5, B6, B7, B8b, B11 and B12) at $20 \mathrm{~m}$ and three bands $(\mathrm{B} 1, \mathrm{~B} 9$ and $\mathrm{B} 10)$ at $60 \mathrm{~m}$ spatial resolution (URL 2).

The Sentinel-2 instrument provides measurements with the following resolutions: the temporal resolution of a satellite, the spatial and the radiometric resolution of an instrument. The spatial resolution of an instrument is the at-ground representation of an individual detector in a satellite sensor array. The spatial resolution of Sentinel-2 is dependent on the particular spectral band (ESA 2015).

Sentinel data is available for anyone via Amazon S3. Free, full and open access to data with very short revisit times, high spatial resolution, and good spectral resolution can benefit several sectors - agriculture, environmental and land-change monitoring, natural disaster response, insurance and others. (URL 2).

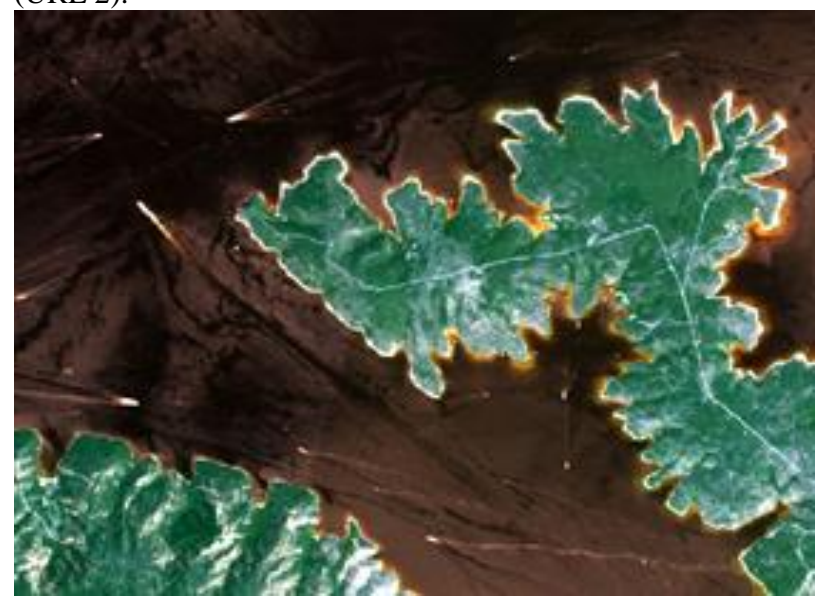

(a) Sentinel image from August 1st 2017

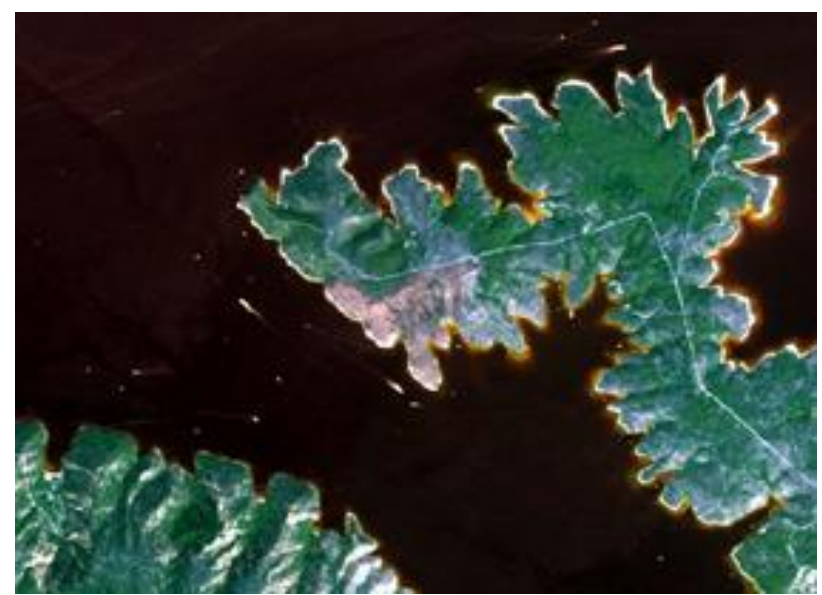

(b) Sentinel image from August 31 2017

Figure 2. Sentinel images of the test field (Source: Amazon S3)

Spectral bands, suitable for fire devastated areas and used for further data processing in this research are: B2, B3, B4, B8, $\mathrm{B} 11$ and B12. Sentinel-2 products are made available to users in SENTINEL-SAFE format, including image data in JPEG2000 format, quality indicators, auxiliary data and metadata (ESA 2015). Spatial reference system assigned with Sentinel images is WGS 84 / UTM zone 33N.
Official cadastral data (cadastral parcels) of cadastral municipality Stari Grad has been purchased from authorized institution in .shp data format and is available in HTRS96/TM reference system.

\section{METHODOLOGY}

Further analysis of collected data has been performed in the GIS environment (Quantum GIS). In order to obtain the multispectral image (Kabal.tif), spectral bands of the Sentinel images have been processed. Obtained images were reprojected from the WGS84/UTM zone 33N to HTRS96/TM reference system so that they can be overlaid with cadastral data.

After that, the processed data was stored in DEMLAS data storage, which serves as central point for accessing the data used for DEMLAS project. DEMLAS represents a prototype of the Multipurpose Land Administration System. DEMLAS data storage is accessed by an interface (Figure 3) that allows searching, browsing and downloading of the required data used for project purposes (Divjak and Roić 2017). Data storage was developed within the DEMLAS project as an infrastructure for research in the field of land governance (Roić et al. 2017).

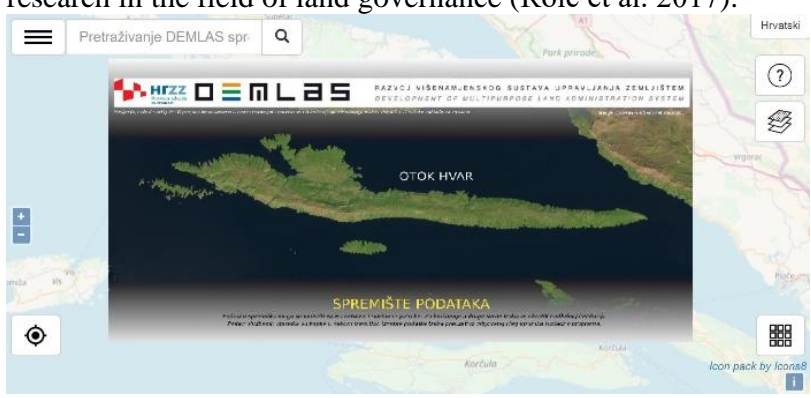

Figure 3. DEMLAS interface

In order to be able to combine this with other existing data in the data storage, burned area data, visible on the Sentinel raster image, was vectorized in .shp format and also stored in the DEMLAS data storage. In this way, all required data for analysis has become available through WMS and WFS service. WFS service was used to load burned area data and official cadastral data (cadastral parcels with land use information) into QGIS as a source data for spatial analysis. By intersecting those two sets of data a new set of data has been produced for calculation of compensations for burned area. New set of data includes following attributes:

$$
\begin{aligned}
& \text { - } \quad \text { cadastral parcel identifier, } \\
& \text { - } \quad \text { land use type, } \\
& \text { area in square meters }-\mathrm{m}^{2} \text { (by QGIS function } \\
& \text { - } \quad \text { area } \$ \text { ), } \\
& \text { area in hectares - ha }\left(\operatorname{area}\left[\mathrm{m}^{2}\right] / 10000\right) \text {. }
\end{aligned}
$$

Compensations for burned area have been calculated according to Methodology for damage assessment in case of natural disasters. Following parameters are required for the calculation:

$$
\begin{array}{ll}
\text { - } & \text { unit price }[H R K / h a], \\
\text { - } & \text { area [ha], } \\
\text { damage }(0 \leq \mathrm{D} \leq 1.0) \text {. }
\end{array}
$$

Unit price is specified in the Rulebook on the methodology for determining the market price for the sale of agricultural land (Official Gazette 2013) which varies in terms of counties, cadastral municipalities and cadastral land use types. For 
cadastral municipality Stari Grad and land use types of arable land, orchards, olive groves and vineyards, unit price is 14586 HRK/ha. Parameter damage (D) refers to value determined by the expert commission during the inspection of the devastated area and can take a value in a range of 0.0-1.0. Since this value is not available, we used an arbitrary value of 0.5 for our test case scenario.

Since the values of required attributes were calculated for the parts of the cadastral parcels, a statistical tool GroupStats from inside the QGIS has been used to sum up individual parts of cadastral parcels.

For calculation of total amount of burned area, calculation of compensations per individual land use and diagrams, Microsoft Office Excel has been used. The final results and diagrams are presented in the following section.

\section{RESULTS ANALYSIS}

By storing the test field data of the Island of Hvar into the DEMLAS data storage, it becomes possible to combine it with the other stored spatial data (georeferenced cadastral map sheets, spatial planning maps, habitat maps, permanent geodetic points etc.). The user can search for required data through DEMLAS Web interface. The search result for cape Kabal is shown in Figure 4. Discovered data can be added and shown on the map (Figure 5), downloaded locally to the computer as a geotiff file or loaded into desired software via WMS service.

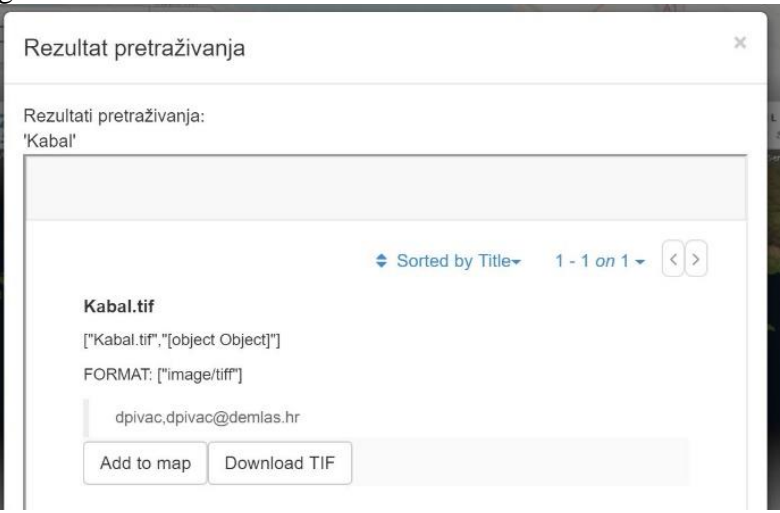

Figure 4. Search results in DEMLAS interface for cape Kabal

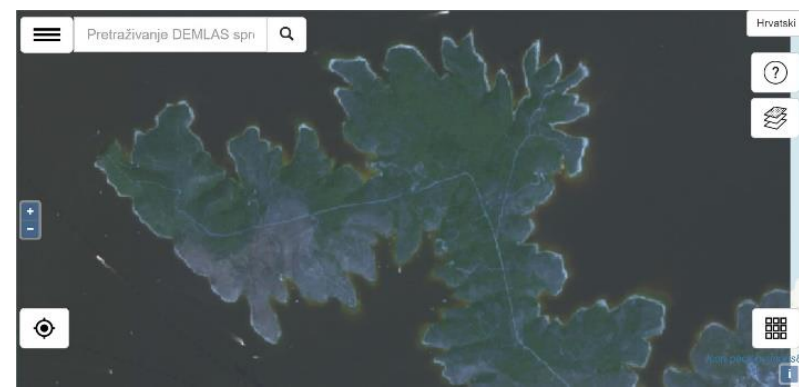

Figure 5. Georeferenced Sentinel image of cape Kabal in DEMLAS interface

In addition to searching and browsing the data, metadata for a particular set of data is also available. It provides users with all relevant information about the type of the data, the creator of data, date when data was created and submitted, WMS and WFS service information, etc. (Figure 6).

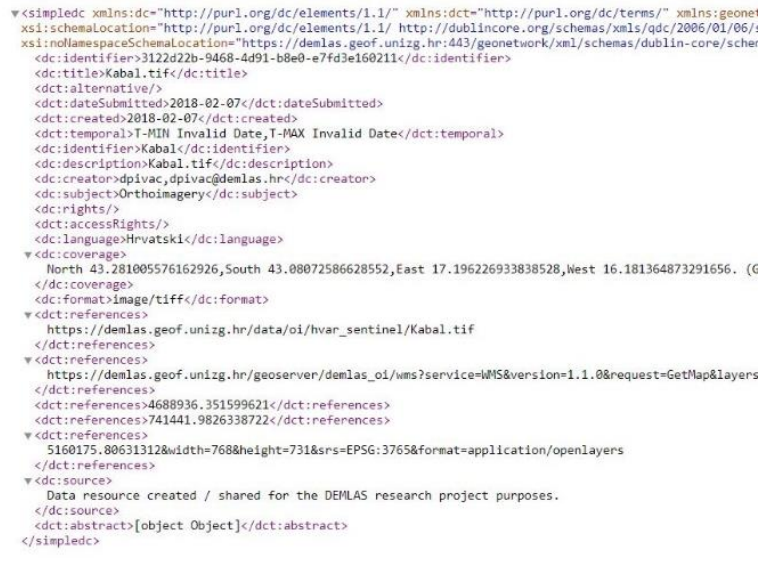

Figure 6. XML metadata file for cape Kabal

Together with discovered georeferenced Sentinel image of the cape Kabal, geometry data about burned area (Figure 7) and cadastral parcels (Figure 8) were loaded into QGIS via WMS and WFS services.

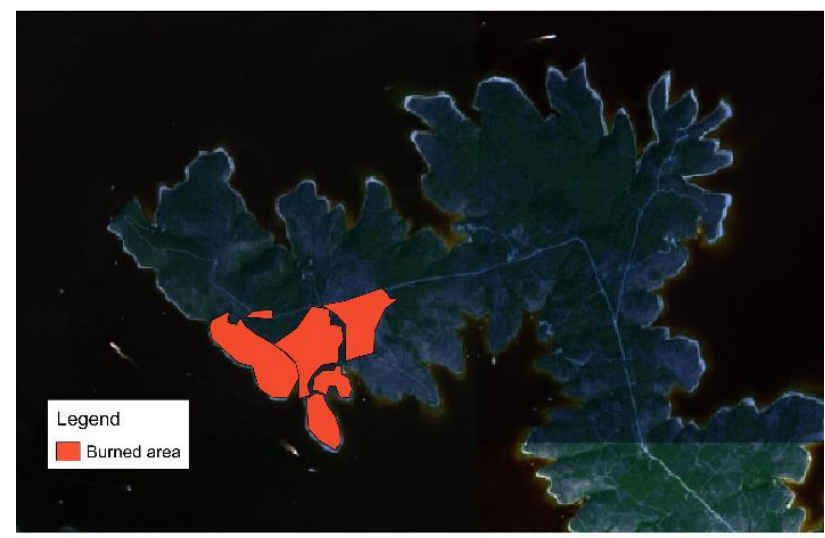

Figure 7. Burned area and Sentinel image in QGIS by using the WMS and WFS service

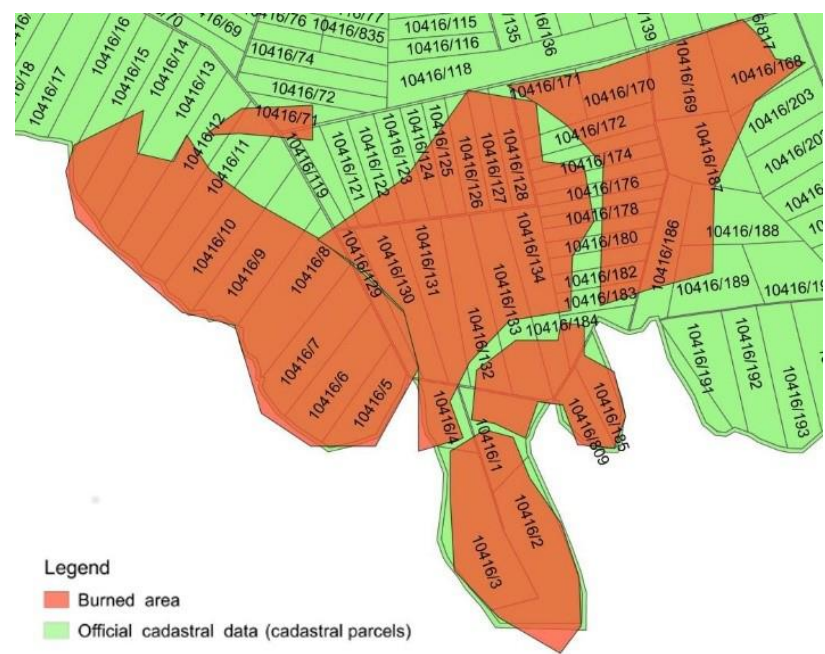

Figure 8. Burned area and official cadastral data (cadastral parcels) in QGIS

Intersection of burned area and cadastral parcels for cadastral municipality Stari Grad resulted with new set of data shown in Figure 9. 
The resulting intersection is the basis for further calculation of areas and compensations. According to the methodology for calculation of compensation values, total results for the burned area were obtained.

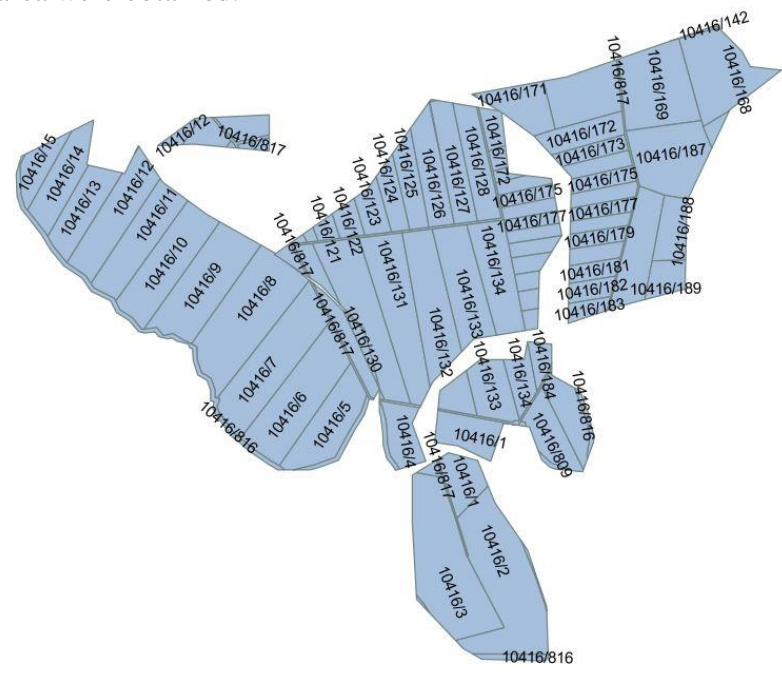

Figure 9. Resulting intersection of burned area and cadastral parcels

The results indicate that the burned area is not too big and totals at 55.02 ha (Table 1). Given that the total number of cadastral parcels in cadastral municipality Stari Grad equals to 17906, it can be derived that $0.34 \%$ of the cadastral parcels, or a total of $1.42 \%$ of the entire cadastral municipality area, were devastated by fire (Table 2 ).

\begin{tabular}{|l|r|}
\hline Number of burned cadastral parcels & 61 \\
\hline Burned area $\left[\mathrm{m}^{2}\right]$ & 550168.94 \\
\hline Burned area $[\mathrm{ha}]$ & 55.02 \\
\hline
\end{tabular}

Table 1. Totals of burned area

\begin{tabular}{|l|r|}
\hline $\begin{array}{l}\text { Number of cadastral parcels in cadastral } \\
\text { municipality }\end{array}$ & 17906 \\
\hline Area [ha] of cadastral municipality & 3872.41 \\
\hline Percentage of affected cadastral parcels & $0.34 \%$ \\
\hline $\begin{array}{l}\text { Percentage of affected cadastral } \\
\text { municipality area }\end{array}$ & $1.42 \%$ \\
\hline
\end{tabular}

Table 2. Totals at the level of cadastral municipality Stari Grad

\begin{tabular}{|l|r|r|}
\hline $\begin{array}{l}\text { Burned area by } \\
\text { land use type }\end{array}$ & \multicolumn{1}{|l|}{$\begin{array}{l}\text { Area } \\
\text { [ha] }\end{array}$} & $\begin{array}{l}\text { Percentage of burned } \\
\text { land use in total area }\end{array}$ \\
\hline arable land & 5.11 & $9.28 \%$ \\
\hline orchards & 19.55 & $35.53 \%$ \\
\hline olive groves & 17.05 & $31.00 \%$ \\
\hline vineyards & 13.31 & $24.19 \%$ \\
\hline
\end{tabular}

Table 3. Burned area by land use type and calculated compensations

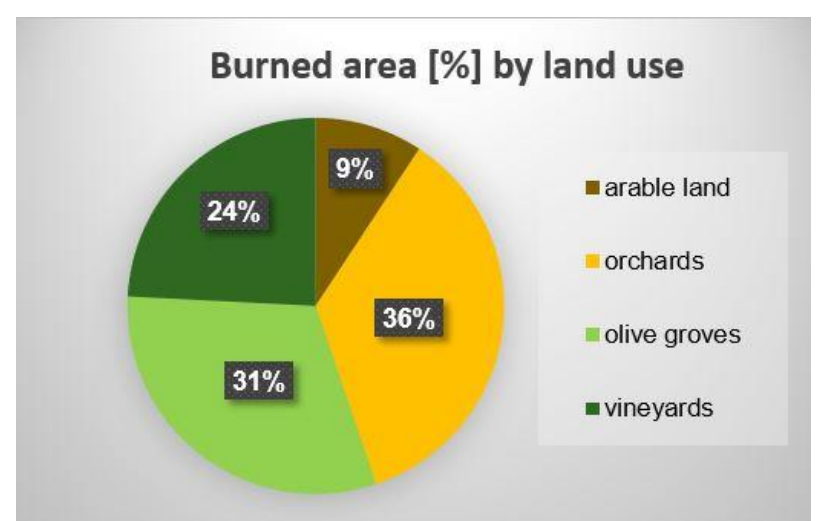

Figure 10. Burned area by land use

According to Methodology for damage assessment in case of natural disasters, compensations for particular land use types have been calculated (Table 4).

\begin{tabular}{|l|c|c|c|c|}
\hline \multicolumn{1}{|c|}{ Land use } & $\begin{array}{c}\text { Unit price } \\
{[\text { HRK/ha] }}\end{array}$ & $\begin{array}{c}\text { Area } \\
{[\text { ha }]}\end{array}$ & $\begin{array}{c}\text { Damage } \\
0 \leq \mathrm{D} \leq 1.0\end{array}$ & $\begin{array}{c}\text { Compensation } \\
{[\text { HRK] }}\end{array}$ \\
\hline \multicolumn{1}{|c|}{$\mathrm{A}$} & $\mathrm{D}$ & $\mathrm{E}$ & $\mathrm{F}$ & $\mathrm{G}=\mathrm{D} \cdot \mathrm{E} \cdot \mathrm{F}$ \\
\hline arable land & 14586 & 5.11 & 0.5 & 37267.23 \\
\hline orchards & 14586 & 19.55 & 0.5 & 142578.15 \\
\hline $\begin{array}{l}\text { olive } \\
\text { groves }\end{array}$ & 14586 & 17.05 & 0.5 & 124345.65 \\
\hline vineyards & 14586 & 13.31 & 0.5 & 97069.83 \\
\hline \hline TOTAL & & 55.02 & & $\mathbf{4 0 1 2 6 0 . 8 6}$ \\
\hline
\end{tabular}

Table 4. Calculation of compensations according to the Methodology

\section{CONCLUSIONS}

Fire devastations are continuous problem in the Republic of Croatia especially in karstic areas of coastal zone during the summer times. Several reasons are contributing this problem. Remote areas which are not suitable for tourism and at the same time not profitable anymore for agriculture or livestock farming because of rocky terrain, are in most cases abandoned or neglected. As a result, wide areas overgrown with vegetation such as shrubs and evergreen trees which are very suitable for becoming a fuel for the wildfires during the dry periods, are constantly increasing. Other problem is human irresponsibility with following the rules how one should behave in such environment. Cigarette butts or glass bottles thrown away in the bushes are very often triggers of the wildfires of catastrophic proportions. After the fire is extinguished, community is facing yet another problem and that is the lacking of the capacity of public authorities to promptly deal with the situation and make decision about compensations.

This paper shows one way of dealing with this problem. Modern technologies provide us with plenty of possibilities for being more efficient. Our test case scenario proved that calculation of compensations can be done in fast and transparent manner with data which can be obtained for free or the state already owns it. Next step which is not shown in this paper would be identifying the owners of fire devastated properties. Main prerequisite for this is existence of up-to-date ownership documentation which unfortunately is not always the case. Currently, significant effort and resources are being 
invested into this subject. Once this process comes to its end, it will open up new possibilities for building a comprehensive and fully functional system as a true support for post-disaster management.

\section{ACKNOWLEDGEMENTS}

This work has been fully supported by the Croatian Science Foundation under project HRZZ-IP-11-2013-7714.

\section{REFERENCES}

Brook A., Polinova, M., Kopel D., Malkinson, D., Wittenberg, L., Roberts, D., Shtober-Zisud, N., 2017. Remote sensing techniques to assess post-fire effects at the hillslope and subbasin scales via multi-scale model, The International Archives of the Photogrammetry, Remote Sensing and Spatial Information Sciences, Hannover, Germany, Vol. XLII-1/W1, pp. 135-141.

Divjak, D., Tutić, D., Roić, M., 2017. Open science in the project "Development of multipurpose land administration system - DEMLAS", Proceedings of 10th Symposium of Croatian Chartered Geodetic Engineers, Opatija, Croatia, pp. 78-82.

DUZS, 2015. Procjena rizika od katastrofa za Republiku Hrvatsku, Državna uprava za zaštitu i spašavanje, Republika Hrvatska.

Fleischhauer, S., Behr, F.-J., Rawiel, P., 2017. Concept and implementation of an architecture for the immediate provision of geodata in disaster management, The International Archives of the Photogrammetry, Remote Sensing and Spatial Information Sciences, Marne La Vallée, France, Vol. XLII4/W2, pp. 73-78.

Jukić, S., Filipi, S., Grgić, M., Bašić, T., 2017. The role of spatial data infrastructure in risk management and hazard control, Proceedings of 10th Symposium of Croatian Chartered Geodetic Engineers, Opatija, Croatia, pp. 21-25.

Mamut, M., Čirjak, B. R., 2017. Prirodno-geografske značajke otoka Hvara. Naše more: znanstveni časopis za more $i$ pomorstvo, 64 (3), pp. 81-91.

Official Gazette of the Republic of Croatia, 1998. Metodologija za procjenu štete od elementarnih nepogoda (in english: Methodology for damage assessment in case of natural disasters), Vol. 96.

Official Gazette of the Republic of Croatia, 2013. Pravilnik o metodologiji utvrđivanja tržišne cijene za prodaju poljoprivrednog zemljišta u vlasništvu Republike Hrvatske izravnom pogodbom (in english: Rulebook on the methodology for determining the market price for the sale of agricultural land owned by the Republic of Croatia by direct contracting), Vol. 141.

Qiu, S., He, B., Yin, C. Liao, Z., 2017. Assessments of Sentinel-2 vegetation red-edge spectral bands for improving land cover classification, The International Archives of the Photogrammetry, Remote Sensing and Spatial Information Sciences, Wuhan, China, Vol. XLII-2/W7, pp. 871-874.
Roić, M., Vranić, S., Kliment, T., Stančić, B., Tomić, H. , 2017. Development of Multipurpose Land Administration Warehouse, Proceedings from FIG Working Week 2017: "Surveying the world of tomorrow - From digitalisation to augmented reality", Helsinki, International Federation of Surveyors, pp. 1-12.

European Space Agency (ESA), 2015. Sentinel-2 User Handbook, 1.2 ed.

Španjol, Ž., Rosavec, R., Barčić D., Filipović, J., 2013. Forest fires in the area of forest administration branch Senj 19912009, Šumarski list, 137 (5-6), pp. 313-323.

Yalcin, M., Kilic, F., Erdogan, S., 2012. Determination of susceptible areas for flooding with geographic information system based multi criteria decision analysis method: example of Istanbul European Site, Proceedings of the 8th International Conference on Geo-information for Disaster Management, Netherlands, pp. 125-133.

Zlatanova, S., Ghawanab, T., Kaurb, A., Neuvelc, J.M.M. , 2014. Integrated Flood Disaster Management And Spatial Information: Case Studies Of Netherlands And India, The International Archives of the Photogrammetry, Remote Sensing and Spatial Information Sciences, Hyderabad, India, Vol. XL-8, pp. 147-154.

URL 1: http://www.unisdr.org/, accessed 1 February 2018.

URL 2: http://sentinel-pds.s3-website.eu-central1.amazonaws.com/, accesed 1 February 2018. 